\title{
S21 - Valor diagnóstico de las proteínas uPAR en sangre para el cáncer gástrico en Guatemala
}

\author{
Irmgardt A. M. Wellmann¹, Carmen I. Villagrán¹, Rafael G. Fernández-Botrán², Elisa Hernández¹, \\ Ericka Mendez ${ }^{3}$, Une Clas ${ }^{3}$
}

${ }^{1}$ Facultad de Ciencias Médicas, Universidad de San Carlos de Guatemala; ${ }^{2}$ University of Louisville, Kentucky, USA; ${ }^{3}$ Universidad de Costa Ric

*Autor al que se dirige la correspondencia: irmgardttina@gmail.com

\section{Resumen}

— 1 cáncer gástrico es la neoplasia más frecuente del tubo digestivo, Guatemala posee tasas de incidencia y de

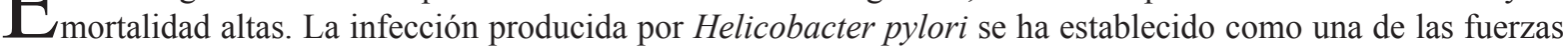
impulsoras de la carcinogénesis gástrica y se ha determinado que la infección con cepas que expresen el factor de virulencia CagA está asociado con lesiones atróficas y precancerosas. El análisis por reacción en cadena de la polimerasa en tiempo real de biopsias del cuerpo gástrico, ha mostrado un incremento significativo de la expresión del activador del plasminógeno de tipo uroquinasa (uPA), su receptor (uPAR) y su inhibidor (PAI-I) en pacientes positivos para $H$. pylori. En esta investigación se planteó determinar el valor diagnóstico de las variantes uPAR en sangre como marcador del riesgo de cáncer gástrico en Guatemala, así como su asociación con la infección de cepas de H. pylori virulentas dentro de la población. Para ello se realizaron pruebas serológicas de H. pylori, CagA y la cuantificación de las proteínas uPAR a los participantes (casos y controles), evidenciándose que la prevalencia de participantes con serología positiva para cepas de $H$. pylori virulentas asciende a $54.9 \%$ y el $18 \%$ corresponde a verdaderos negativos para $H$. pylori cagA negativos. Se demostró que existe diferencia significativa en las medias de las cuantificaciones de uPAR entre casos y controles. La curva ROC mostró que resulta razonable plantear que la cuantificación de uPAR es una prueba diagnóstica con capacidad aceptable de discriminar pacientes con y sin cáncer gástrico.

Palabras claves: Proteínas uPAR, CagA, Helicobacter pylori

\section{Abstract}

Gastric cancer is the most common malignancy of the digestive tract. Guatemala has high incidence rates and mortality. Infection by Helicobacter pylori has been established as one of the driving forces for gastric carcinogenesis and determined that infection with strains expressing the virulence factor CagA are associated with atrophic and precancerous lesions. Analysis by polymerase chain reaction in real time biopsy of the gastric body, has shown a significant increase in the expression of plasminogen activator urokinase (uPA), its receptor (uPAR) and its inhibitor (PAI-I) in patients positive for $\mathrm{H}$. pylori. This research was raised to determine the diagnostic value of uPAR variants in blood as a marker of gastric cancer risk in Guatemala, as well as its association with infection with virulent $H$. pylori strains within the population. Serological tests for $H$. pylori, CagA and quantification of proteins UPAR among participants (cases and controls) were done, showing that the prevalence of participants with positive serology for $H$. pylori virulent strains amounts to $54.9 \%$ and $18 \%$ are negative for $H$. pylori true negative cagA. Finally, it was shown that there is significant difference in mean quantifications uPAR between cases and controls. The ROC curve showed reasonable to propose that resulting quantifying uPAR is an acceptable diagnostic ability to discriminate patients with and without gastric cancer test.

Keywords: uPAR proteins, CagA, Helicobacter pylori 